\title{
Aestivo-hibernation of Coccinella septempunctata (Coleoptera: Coccinellidae) in a mountainous area in southern Turkey: Is dormancy at high altitudes adaptive?
}

\author{
ÖZLEM GÜVEN ${ }^{1}$, HASAN GÖLLÜOĞLU ${ }^{1}$ and Piotr CERYNGIER ${ }^{2}$ \\ ${ }^{1}$ Biology Department, Kahramanmaraş Sütçü Imam University, Kahramanmaraş, 46100, Turkey; e-mails: okalkar@hotmail.com; \\ h_golluoglu@hotmail.com \\ ${ }^{2}$ Faculty of Biology and Environmental Sciences, Cardinal Stefan Wyszyński University, Wóycickiego 1/3, 01-938 Warsaw, Poland; \\ e-mail: p.ceryngier@uksw.edu.pl
}

Key words. Coleoptera, Coccinellidae, Coccinella septempunctata, dormancy, ecological trap, Beauveria, Dinocampus coccinellae, Turkey

\begin{abstract}
Each year huge numbers of adults of Coccinella septempunctata occupy aestivo-hibernation sites on Uludaz Hill, Çimen Mountain in the Kahramanmaraş Province of Turkey. In 2008 and 2009 we investigated the phenology, population dynamics, mortality and natural enemies of $C$. septempunctata arriving on Uludaz Hill. Samples were collected once a month during the snow-free season (April-November) from the top of the hill (2273 m a.s.1.) and at two lower altitudes (1900 m a.s.1. and $2050 \mathrm{~m}$ a.s.1.) on the slopes of the hill. In both years C. septempunctata was clearly more abundant at the top of the hill than at the two lower altitudes, which is in accordance with the hypothesis that beetles migrating to dormancy sites are strongly attracted to sites at the highest altitudes. Numbers of C. septempunctata on the hill were low in April and May. The large increase in abundance recorded in June may be attributed to the arrival of a new generation from lowland breeding sites. Emergence of previous year colonizers from their winter shelters is less probable due to the high fat content of the beetles collected in June. Spring dispersal from the hill to lowland areas was not observed. We suppose that this dispersal was either prevented by low temperature or considerably delayed and not synchronized with the period of ladybird breeding activity in the surrounding lowlands. In addition, the C. septempunctata aestivo-hibernating on Uludaz Hill suffered very high mortality, mainly caused by entomopathogenic fungi of the genus Beauveria. The results of our study are discussed in terms of the ecological trap concept.
\end{abstract}

\section{INTRODUCTION}

The seven spot ladybird, Coccinella septempunctata L., exhibits great ecological plasticity in terms of various aspects of its life cycle, such as reproductive behaviour, voltinism and dormancy (Hodek \& Michaud, 2008). In this species, among others, the length of dormancy and type of dormancy site chosen are very variable. In central Europe some individuals enter diapause as early as August, while others are still active in October. Aestivo-hibernation of the former is often preceded by a hypsotactically oriented migratory flight to dormancy sites situated on the tops of prominent hills or mountains. In contrast, individuals that remain active for longer usually hibernate in lowland areas, near breeding sites (Hodek et al., 1993; Hodek, 2012). The two types of individuals differ in their spatial distributions: lowland hibernators spend the cold months singly or in small groups, while mountain aestivo-hibernators often form large aggregations (Hodek, 2012).

In warmer regions, including the Mediterranean Basin and Middle East, where C. septempunctata breeds in early spring and the subsequent hot and dry season is more hostile to the ladybird and its prey, migrations to high altitude sites start as early as June (Bodenheimer, 1943; Katsoyannos et al., 1997a, b; Ricci et al., 2005). One such high altitude site, where mass appearances of $C$. septempunctata occur early in the season is an area on the top of Uludaz
Hill, Çimen Mountain near Kahramanmaraş in southern Turkey. At this locality impressive aggregations of C. septempunctata (Fig. 1) occur every year throughout the warm season. Interviews with local people revealed that the beetles have done this for more than 100 years.

The main aim of this study was to investigate phenology, population dynamics and altitudinal differentiation of $C$. septempunctata on Uludaz Hill. As dormant ladybirds often suffer a high mortality due to abiotic factors and many different natural enemies (Ceryngier, 2000; Ceryngier et al., 2012), we also assessed the effect of the natural enemies on C. septempunctata and the mortality of this coccinellid while on the top of Uludaz Hill.

\section{MATERIAL AND METHODS}

This study was carried out in 2008 and 2009 on Uludaz Hill, Çimen Mountain in Kahramanmaraş Province ( $\left.37^{\circ} 55^{\prime} \mathrm{N}, 36^{\circ} 39^{\prime} \mathrm{E}\right)$. Samples were collected in the area of the peak of the hill (2273 $\mathrm{m}$ a.s.l.) and on the slopes of the hill at two lower altitudes (1900 $\mathrm{m}$ a.s.1. and $2050 \mathrm{~m}$ a.s.1.). The substratum at all sampling sites mostly consisted of rocks and stones and the vegetation was very sparse (Fig. 2).

\section{Population density}

C. septempunctata density was assessed once a month during the snow-free season (from April to November). The dates of sampling in 2008 were: 19 April, 3 May, 7 June, 16 August, 20 September, 20 October and 25 November, and in 2009: 11 April, 


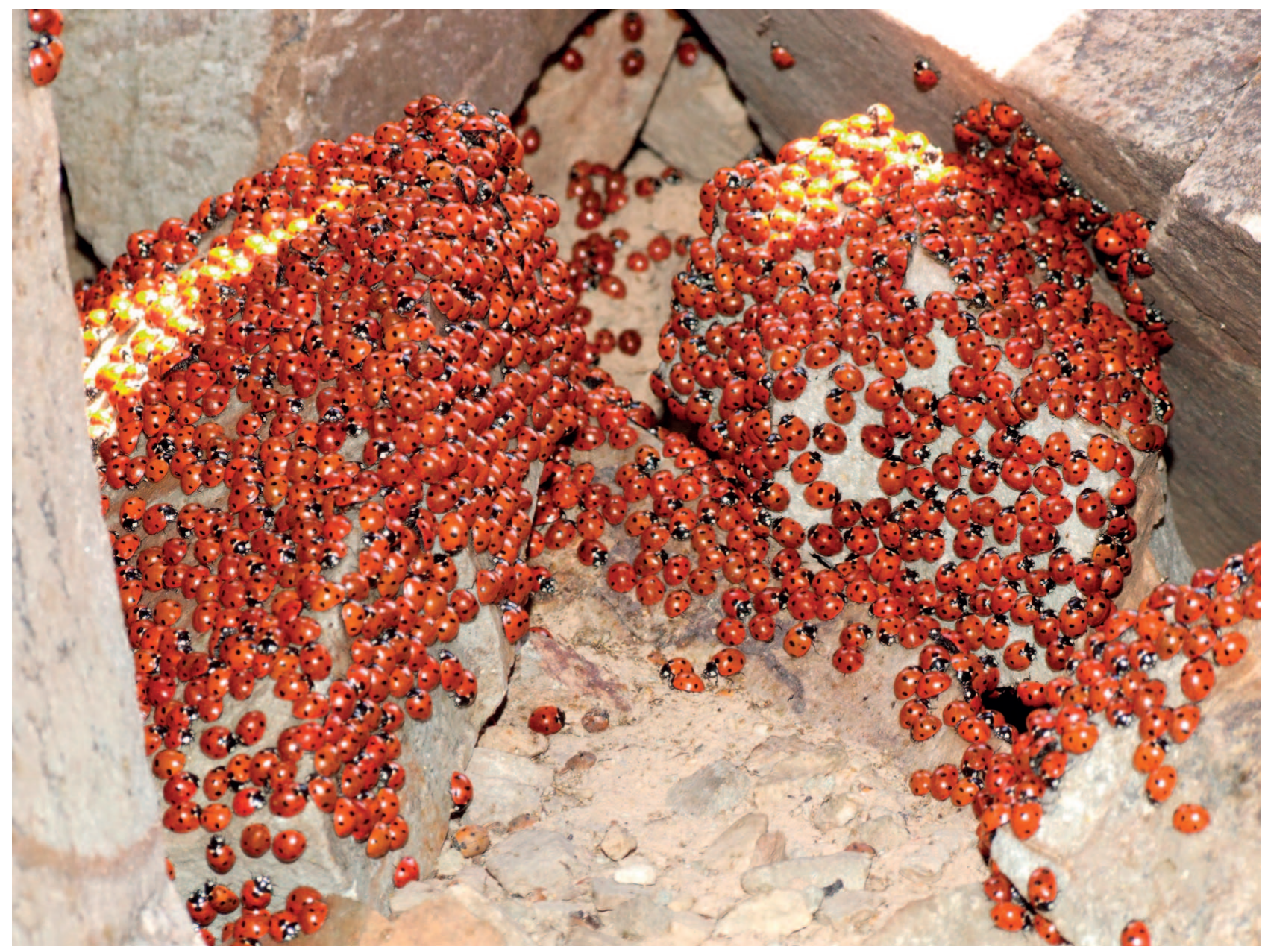

Fig. 1. Coccinella septempunctata aggregating on the top of Uludaz Hill (photographed 7 June 2008).

1 May, 10 June, 14 July, 15 August, 8 September, 17 October and 21 November. At each of the three altitudes numbers were recorded at sites with a northerly $(\mathrm{N})$, easterly $(\mathrm{E})$, southerly $(\mathrm{S})$ and westerly $(\mathrm{W})$ aspect, respectively. The beetles were counted in three randomly selected $1 \mathrm{~m}^{2}$ plots at each site and date. Only beetles visible on rocks, stones or plants were counted.

\section{Physiological state}

From May to October 2009, samples of 30-60 individuals of $C$. septempunctata were collected at the peak of the hill. They were subsequently dissected in Ringer solution under a stereomicroscope to record the state of their fat bodies, digestive tracks and in the case of females their ovaries. Fat body size was assessed as small, medium-sized or large. Maturation level of ovaries was evaluated, after Sakurai et al. (1986), using a 5-stage scale, from stage 1 for undeveloped germaria containing oogonia to stage 5 for ovarioles with mature eggs.

\section{Potential mortality factors}

In both years, between June and October, live C. septempunctata were collected once a month from the peak of the hill. Each sample consisted of more than 200 individuals. They were brought to the laboratory and reared in glass containers at $24 \pm 2{ }^{\circ} \mathrm{C}$ and 60 $\pm 10 \%$ relative humidity, with water and honey solution provided. Ten to 15 days after sampling, the beetles were checked daily for mortality and emergence of parasitoids and dead individuals were removed from the rearing containers. Ladybirds dying at that time, except those killed by parasitoids, were checked for fungal infection. They were placed in Petri dishes with moist fil- ter paper and kept at $25^{\circ} \mathrm{C}$ to stimulate the growth and sporulation of fungi on infected dead individuals. Spores produced by the mycelia overgrowing beetle cadavers were then incubated on potato dextrose agar. Fungus identification was done using slide culture techniques (Lacey, 1997).

\section{Statistical analysis}

We used multifactor ANOVA to reveal the relationships between the dependent variable (C. septempunctata density) and the three explanatory variables (altitude, aspect of slope and sampling time).

As our data were highly right-skewed with many zero values it was Box-Cox transformed in order to meet ANOVA assumptions. $\mathrm{R}$ statistical software was used in the analyses.

\section{RESULTS}

\section{Population dynamics of $\boldsymbol{C}$. septempunctata}

Multifactor ANOVA revealed that in both years of this study altitude, site and time of sampling had highly significant effects on the density of $C$. septempunctata, while a significant effect of the aspect of the slope was recorded only in 2009 (Table 1). Post hoc comparisons (Tukey test) revealed that in that year the ladybird densities on the southand east-facing slopes were not significantly different $(\mathrm{P}=$ $0.54)$, but were significantly lower on the west-facing slope ( $\mathrm{P}=0.003$ and $\mathrm{P}<0.001$ for $\mathrm{W}-\mathrm{S}$ and $\mathrm{W}-\mathrm{E}$ comparisons, respectively). In comparison with the densities occurring 


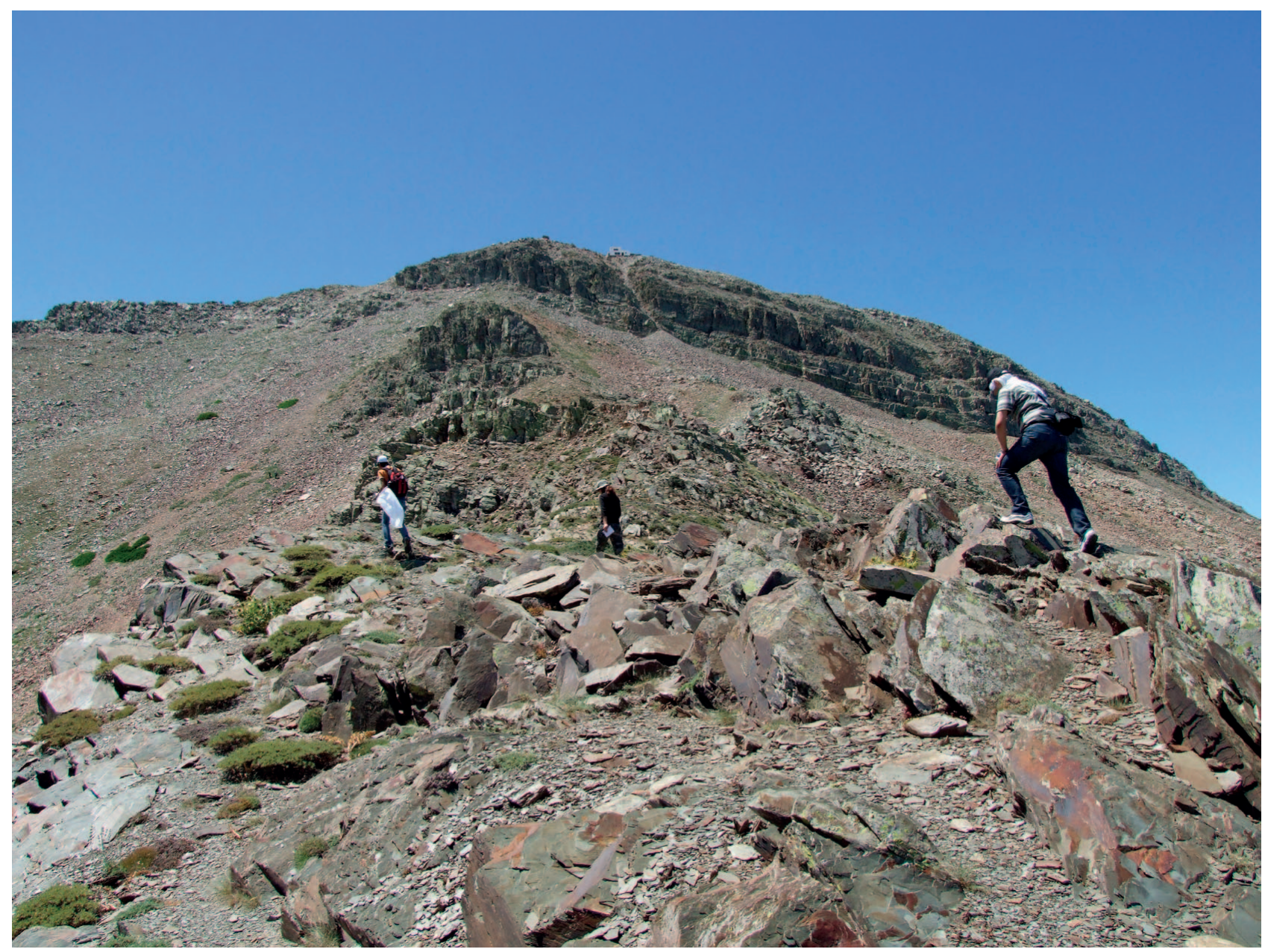

Fig. 2. General view of higher parts of Uludaz Hill.

on slopes of other aspects that on the northern aspect was much lower $(\mathrm{P}<0.001)$.

Although the abundance of $C$. septempunctata was distinctly higher in 2008 than in 2009 (91,060 individuals recorded in 2008 vs. 20,406 in $2009=4.5$ times higher), a very clear altitude-density pattern was recorded in both years and each aspect; the ladybirds tended to be much more abundant in the peak area of the hill than at lower altitudes (Figs 3 and 4).

In 2008, only a few C. septempunctata were found in April (mean densities 2.1, 3.1 and 0.6 individuals per $\mathrm{m}^{2}$ at 1900,2050 and $2273 \mathrm{~m}$ a.s.1., respectively) and May (1.2 ind. $/ \mathrm{m}^{2}$ at $1900 \mathrm{~m}$ a.s.l. and none at the two higher altitudes). However, already in June the ladybird num- bers reached the seasonal maximum (133 ind. $/ \mathrm{m}^{2}$ at 1900 $\mathrm{m}$ a.s.l., 226 ind. $/ \mathrm{m}^{2}$ at $2050 \mathrm{~m}$ a.s.l. and 2723 ind. $/ \mathrm{m}^{2}$ at $2273 \mathrm{~m}$ a.s.1.). Later in the season, the numbers gradually decreased and in November a few individuals $\left(9.4\right.$ per $\left.^{2}\right)$ were recorded only in the area of the peak (Fig. 3).

In 2009, the first individuals of $C$. septempunctata were recorded in May and the last in October. Relatively high numbers were recorded in June, August and September, with lower densities in July (Fig. 4).

\section{Physiological state of $C$. septempunctata}

The guts of all the C. septempunctata individuals dissected between May and October 2009 did not contain any food or contained brown fluid without distinguishable food particles.

TABLE 1. The effects of altitude, aspect and month and their interactions on the densities of Coccinella septempunctata recorded on Uludaz Hill (multifactor ANOVA of the Box-Cox transformed data).

\begin{tabular}{lccccc}
\hline \multirow{2}{*}{ Explanatory variable } & \multicolumn{2}{c}{2008} & & \multicolumn{2}{c}{2009} \\
\cline { 2 - 4 } \cline { 5 - 6 } & $\mathrm{F}$ & $\mathrm{P}$ & $\mathrm{F}$ & $\mathrm{P}$ \\
\hline Altitude & 190.671 & $<0.001$ & 403.150 & $<0.001$ \\
Aspect & 0.239 & 0.869 & 30.834 & $<0.001$ \\
Sampling time & 328.490 & $<0.001$ & 289.795 & $<0.001$ \\
Altitude $\times$ aspect & 2.769 & 0.013 & 2.954 & 0.009 \\
Altitude $\times$ sampling time & 23.702 & $<0.001$ & 29.598 & $<0.001$ \\
Altitude $\times$ aspect $\times$ sampling time & 2.897 & $<0.001$ & 3.993 & $<0.001$ \\
\hline
\end{tabular}


$\square 1900 \mathrm{~m}$ a.s.I. $\square 2050 \mathrm{~m}$ a.s.I. $\mathbf{\square} 2273 \mathrm{~m}$ a.s.I.
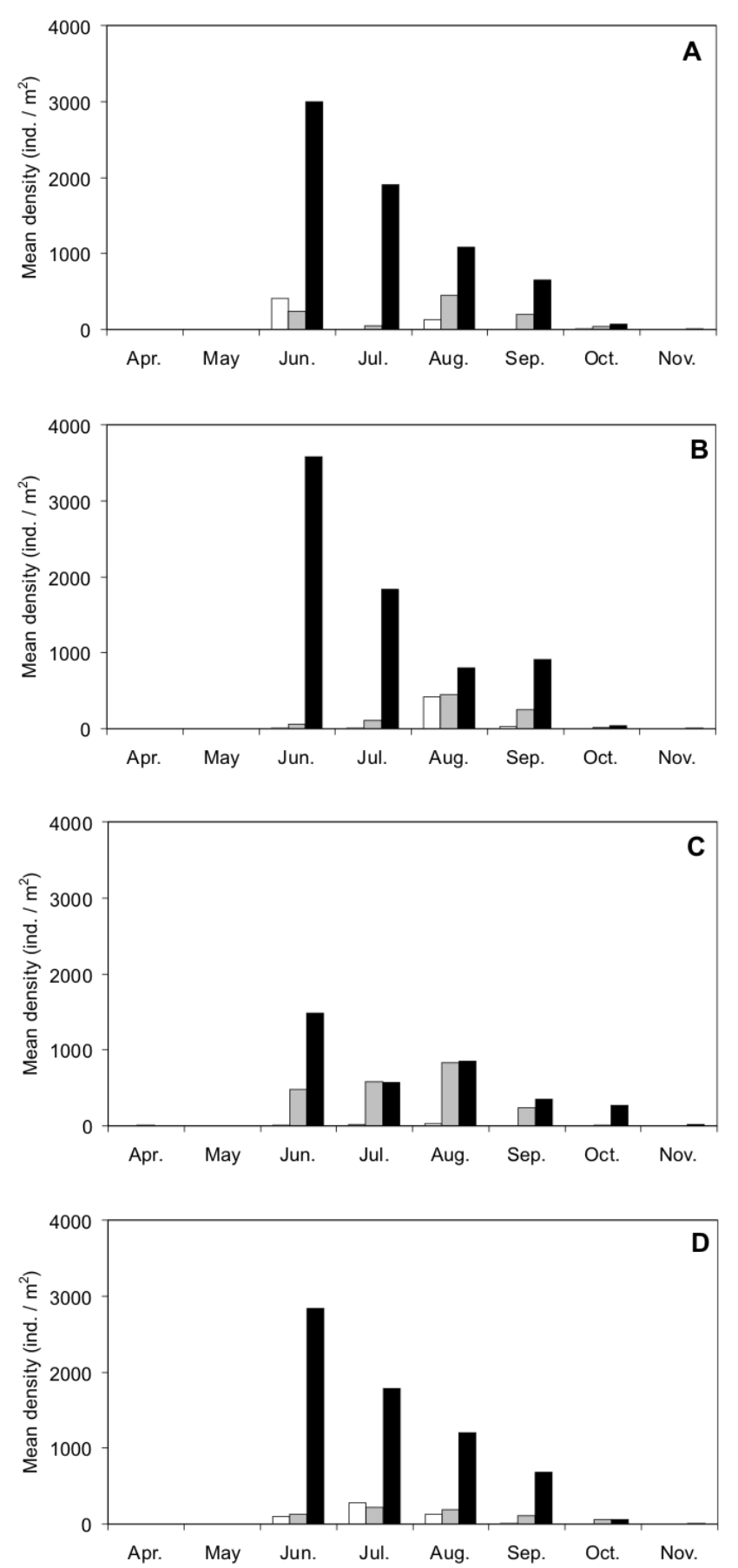

Fig. 3. Mean densities of Coccinella septempunctata at three altitudes on Uludaz Hill in 2008. A - north-, B - east-, C - southand D - west-facing slopes.

Ovaries of all but one of the females dissected were undeveloped, with oogonia or early oocytes showing no traces of yolk deposition (stages 1-2). The initial phase of oocyte vitellinization (stage 3 ) was recorded only in one female in the October sample.

Percentages of $C$. septempunctata with different amounts of fat changed with the season. The May sample included a mixture of beetles with small (28\%), medium-sized (18\%) and large (54\%) fat bodies. Later, between June and August, individuals with extensive fat reserves clearly
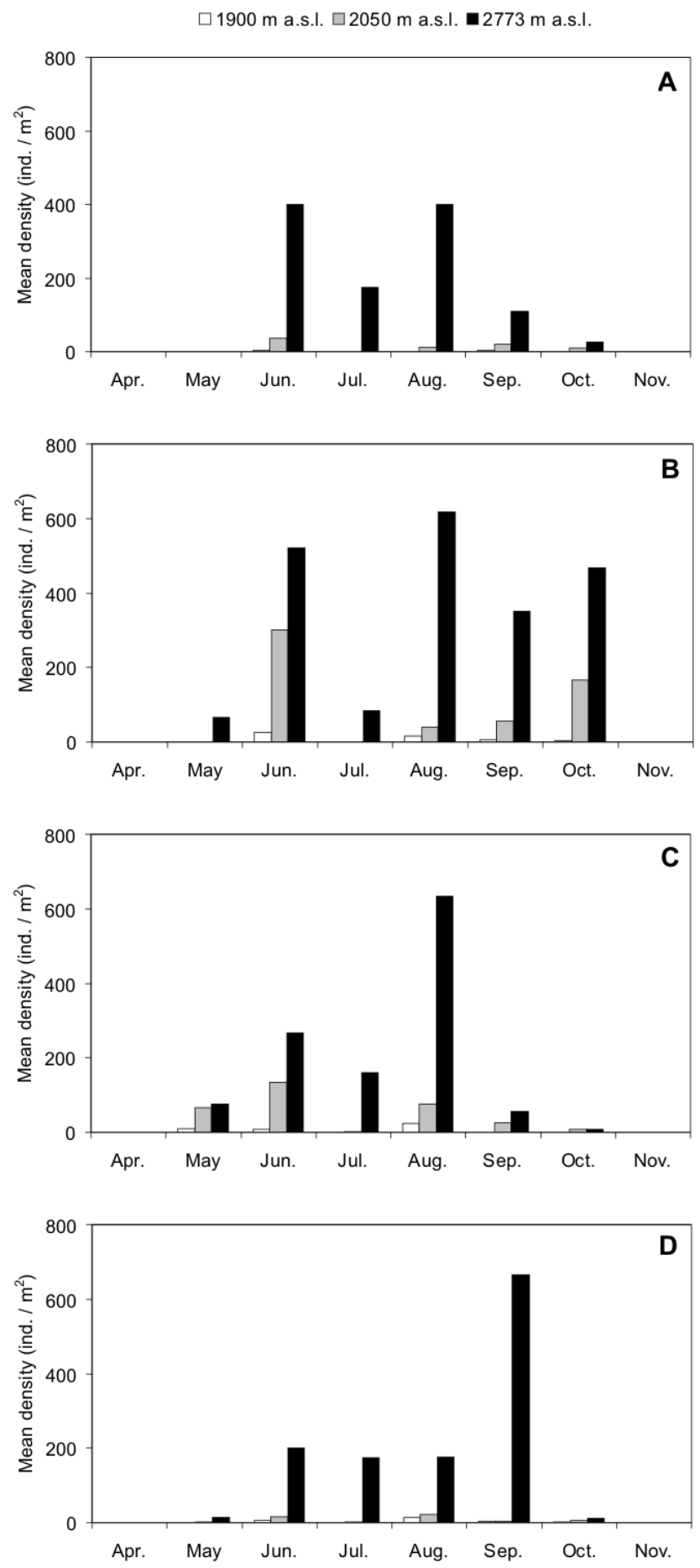

Fig. 4. Mean densities of Coccinella septempunctata at three altitudes on Uludaz Hill in 2009. A-D - as in Fig. 3.

predominated (92-100\%), but their percentage was much lower in September (45\%) and October (33\%) (Fig. 5).

\section{Mortality factors of $C$. septempunctata}

Two mortality factors were identified in field collected C. septempunctata: the braconid parasitoid Dinocampus coccinellae (Schrank) and the entomopathogenic fungi of the Beauveria bassiana Balsamo (Vuillemin) group.

All the field collected beetles dying in the experimental rearing were found to be either parasitized by $D$. coc- 

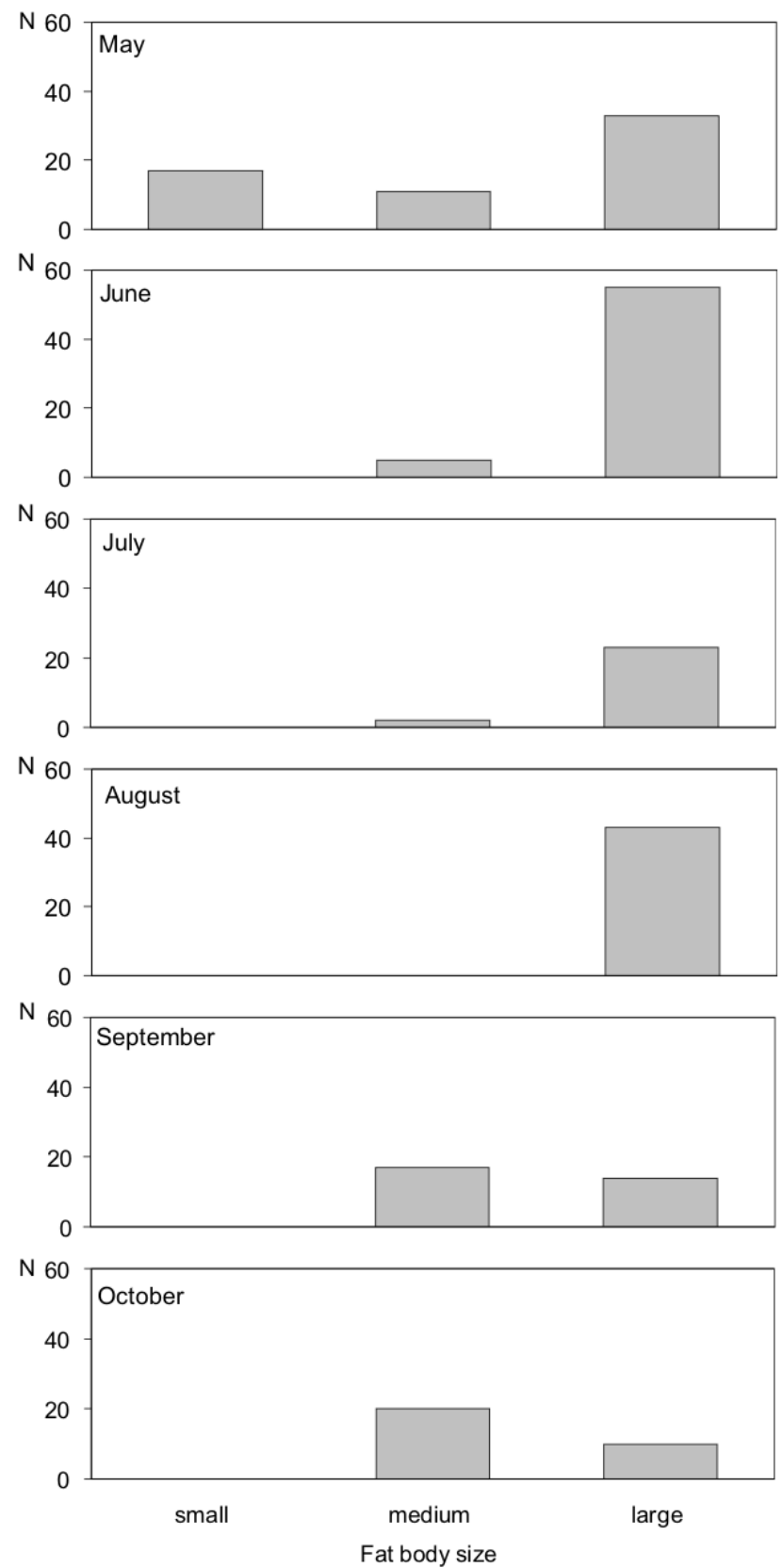

Fig. 5. Fat body size in individuals of Coccinella septempunctata collected between May and October 2009 at the top of Uludaz Hill

cinellae or infected with Beauveria. The prevalence of $D$. coccinellae in individual samples ranged between $2 \%$ and $15 \%$ in 2008 and $0.3 \%$ and $4 \%$ in 2009 . The respective values for infection with Beauveria were 2-78\% in 2008 and $1-78 \%$ in 2009 . The total C. septempunctata mortality due to these two factors ranged in individual months between $6 \%$ and $93 \%$ in 2008 and $5 \%$ and $77 \%$ in 2009 . Especially high mortalities were recorded in August 2008 and August and October 2009 (Fig. 6).

\section{DISCUSSION}

\section{Phenology}

Ladybird beetles overwintering on the tops of hills and mountains usually return to the lowlands in spring to repro-

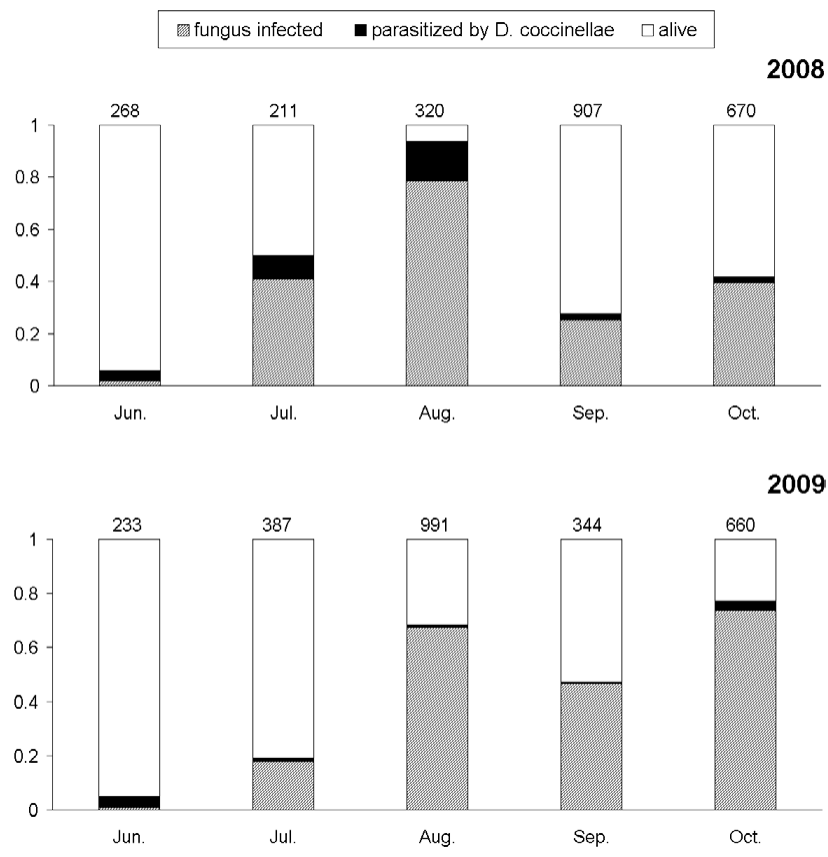

Fig. 6. Proportion of Coccinella septempunctata collected from the top of Uludaz Hill infected with Beauveria and parasitized by Dinocampus coccinellae. Numbers above the bars are sample sizes.

duce (Hodek, 1960, 2012). After spring dispersal, a certain time elapses before the tops are recolonized by a new generation of beetles. Our two-year investigations showed that in the area of the peak of Uludaz Hill C. septempunctata occurs throughout the snow-free season and that over this period they have empty guts and immature ovaries, which is the state typical of dormant individuals (Hodek, 2012).

In the lowlands surrounding Uludaz Hill, mating and egg-laying by $C$. septempunctata take place in late April and early May (Ö. Güven, unpubl. data). At that time, the higher parts of the hill are often covered with snow below which the ladybirds are hidden in their winter shelters. When the snow melts around May, it is probably still too cold for most of $C$. septempunctata to leave their hiding places and fly to lowland areas. In June, when the air temperature rises to about $8-10^{\circ} \mathrm{C}, \mathrm{C}$. septempunctata appear in great numbers on rocks, stones and plants, and their walking and flying activity is high. This may be related to both the emergence of hibernating individuals from their winter shelters and the immigration of a new generation of beetles from lowland breeding sites. According to Bodenheimer (1943) and Katsoyannos et al. (1997a,b), most $C$. septempunctata in the Mediterranean region migrate to the mountains in June, at the beginning of the hot season. However, our data on fat body dynamics, especially the relatively high percentage of fatty individuals in the May sample, may indicate that some well-fed beetles arrive at Uludaz Hill very early, already before June. Almost exclusive occurrence of individuals with extensive fat bodies found in the following months (June-August) is probably due to disappearance (mortality and/or dispersal) of the previous season's aestivo-hibernators. The state of the fat bodies of the individuals in the late samples (September 


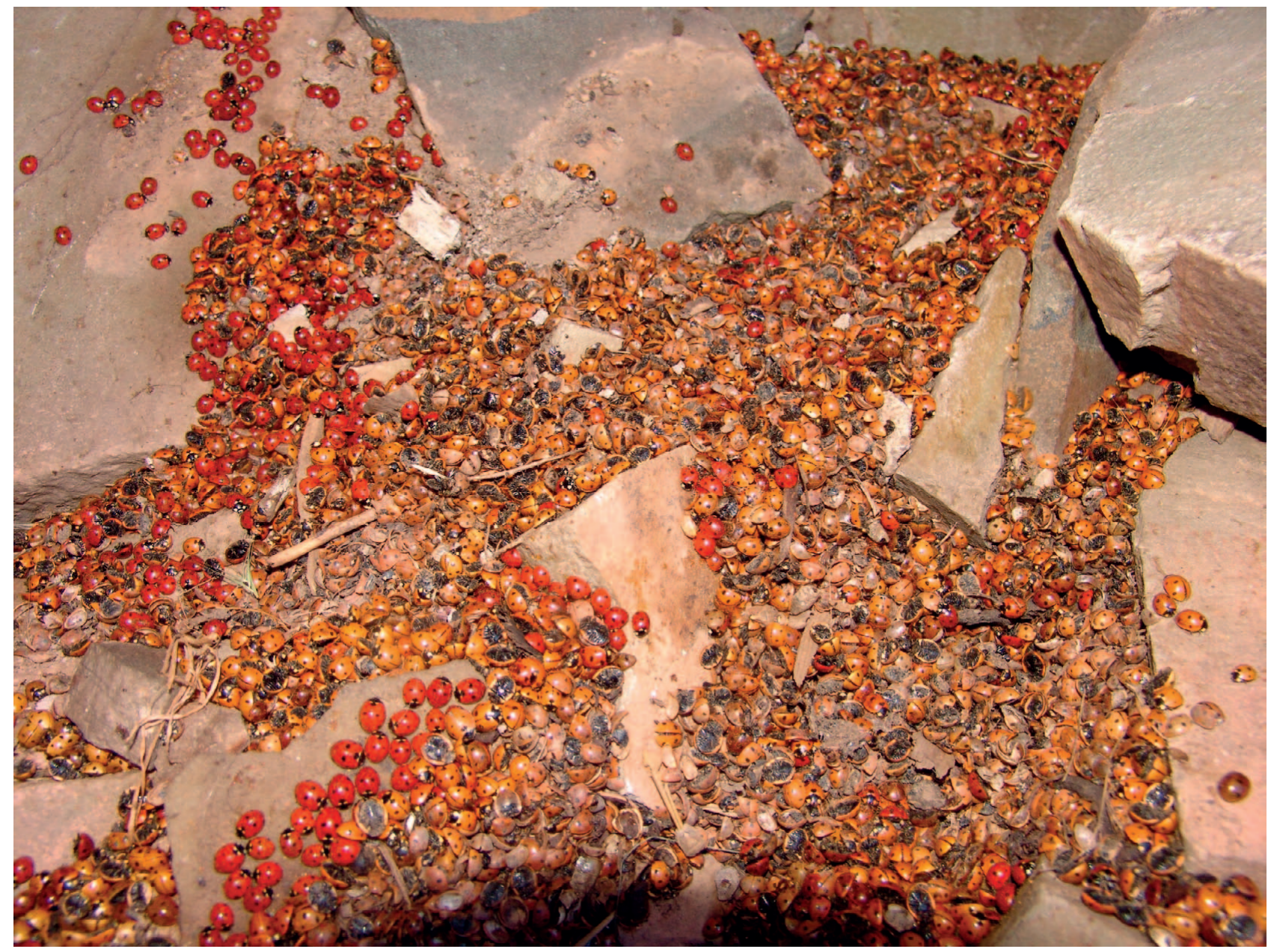

Fig. 7. Large numbers of dead Coccinella septempunctata at the top of Uludaz Hill (photographed 7 June 2008).

and October) suggests that in some of the individuals the fat reserves were substantially depleted before winter.

We did not observe the dispersal of C. septempunctata from the top of Uludaz Hill. It can be deduced that due to climatic constraints this could not happen earlier than June, when the reproductive activity of $C$. septempunctata in lowlands has already ceased and the adults of a new generation migrate in the opposite direction. Bodenheimer (1943) found that the life-cycle of C. septempunctata in the central part of Turkey is univoltine, with a prolonged aestivo-hibernation lasting from early summer till Aprilearly May of the next year. The results of our study are generally in accordance with Bodenheimer's finding with the exception that on Uludaz Hill aestivo-hibernation terminates so late the year that there is little or no time for them to disperse and breed.

\section{Natural enemies}

Spending many months in dense aggregations, the ladybirds on Uludaz Hill were subject to attack by natural enemies, especially entomopathogenic fungi of the genus Beauveria. They could not be reliably identified to species level in this study because, as recent investigations suggest, the fungi traditionally classified as B. bassiana are actually a group of cryptic species, which are difficult to separate (Rehner et al., 2011). The enormous numbers of dead C. septempunctata, often overgrown by pathogen mycelium, recorded in dormancy shelters (Fig. 7), provide good evidence of this. Also, the high prevalence of mycosis among field collected beetles that died in the laboratory rearings indicates that the scale of infection was severe. The maxima in the scale of infection in the reared ladybirds were recorded in the late samples (August in 2008 and October in 2009), which suggests that the infected individuals were new generation individuals that had recently arrived on the hill. Infected beetles of the previous generation were probably killed by the fungi before June (the first sampling date) while they were still in hibernation. It is reported by various authors (Lipa et al., 1975; Mills, 1981; Ceryngier, 2000) that in the late phase of dormancy the mortality caused by Beauveria is especially high.

The role of $D$. coccinellae in limiting the numbers of C. septempunctata on Uludaz Hill was much smaller than that of Beauveria. Although parasitoids emerged from the ladybirds in each sample, the percentage emergence was usually low (a few percent), which is consistent with the finding of Ceryngier (2000) that the rates of parasitization of $C$. septempunctata by $D$. coccinellae at montane sites are low in comparison with the rates recorded at sites at lower altitudes. 


\section{Maladaptive aspects of $C$. septempunctata aestivo- hibernating high on mountain tops}

Honĕk (1989) records that harsh weather conditions may impede the spring dispersal of ladybirds that hibernate on mountain tops. Extensive epizootics caused by fungal pathogens were found to be the other disadvantage of hibernating or aestivo-hibernating on the tops of mountains (Ceryngier, 2000). This study provides further evidence that these two phenomena may negatively affect $C$. septempunctata arriving at dormancy sites in high mountains. Due to an innate hypsotactic tendency, migrating individuals are probably strongly attracted to high summits, where they form very dense aggregations facilitating the spread of mycosis. Individuals that survive the prolonged dormancy period in an environment rich in the spores of fungal pathogens may then be 'imprisoned' on the mountain tops by long-lasting adverse weather conditions. As previously found (Honĕk, 1989; Ceryngier, 2000), long distance migrants to high mountains, which subsequently experience the above mentioned disadvantages, are relatively large and predominantly female. As to the potential fecundity and vitality they constitute the "fittest" part of the population as the smaller individuals cannot migrate or only migrate for shorter distances.

It seems that the case reported here can be interpreted in terms of the ecological trap concept. An ecological trap is defined as a low-quality habitat that is preferred by organisms over high-quality habitats (Battin, 2004). The empirical evidence for the existence of ecological traps mostly concerns anthropogenically modified habitats (Schlaepfer et al., 2002; Battin, 2004; Robertson \& Hutto, 2006), but some natural habitats can also act as traps (see e.g. Purcell \& Verner, 1998; Ries \& Fagan, 2003). Theory assumes that the presence of ecological traps should imply local extinction or at least decline of the species so trapped (Schlaepfer et al., 2002; Battin, 2004; Robertson \& Hutto, 2006). However, in the case of "natural traps", such as that described here, which persist in the environment for much longer than "anthropogenic traps", some kind of equilibrium between the deleterious effect of the trap and population persistence must exist. As previously emphasized, individuals may have a broader choice than between unsuitable but preferred and suitable but avoided habitats (Kristan, 2003; Battin, 2004). There may be a continuum of habitats differing in suitability and attractiveness. Moreover, as migration between habitats is energetically costly, some attractive but distant habitats may be unreachable by part of the population. The tendency of $C$. septempunctata to migrate to the mountain tops may thus represent a kind of relatively 'benign' trap, where only strong individuals, capable of performing long-distance flights, are trapped on the highest summits while other individuals either migrate to hills at lower altitudes or remain in the lowlands.

The hypsotactic migratory behaviour of C. septempunctata cannot be completely maladaptive. There are certainly benefits from flight to high altitude dormancy sites. Zhou et al. (1995), for example, found that mountain hibernators use less of their fat reserves during hibernation than low- land ones, which may increase winter survivorship of the former and positively affect their subsequent activities in spring, such as dispersal to breeding areas or reproduction. Dormancy at moderately high altitudes where there are low or moderate densities of pathogen spores may therefore be more profitable than hibernating in lowland sites. The problem arises when dormancy sites are situated high in the mountains and/or there are high pathogen densities there. Selection by C. septempunctata of very high altitude sites is probably not rare in high mountain regions, taking into account numerous papers reporting this. For example, Ricci et al. (2005) record migration of beetles up to1940 m a.s.l. in the Sibillini Mountains (central Italy), Ansaripour et al. (2012) collected dormant C. septempunctata at altitudes between 1700 and 1900 m a.s.l. in western Iran, and Özbek \& Çetin (1991) record aggregations of seven spot ladybirds as high as $2900 \mathrm{~m}$ a.s.1. in eastern Anatolia (Turkey). C. septempunctata is also recorded at very highly altitude dormancy sites in other Asiatic regions. According to Savoiskaya (1966), the high mountain overwintering sites of $C$. septempunctata in south-eastern Kazakhstan range between 2600 and $3300 \mathrm{~m}$ a.s.l. and those in Tajikistan reported by Ataeva (1972) between 2500 and $3000 \mathrm{~m}$ a.s.1.

ACKNOWLEDGEMENTS. This project was supported by Kahramanmaraş Governor and Kahramanmaraş Sütçü İmam University (Project Number: 2008/1-38M). We are grateful to F. Güven for mountaineering advice, Ö. Baltac1, and A. Avize for their technical help and H. Çanak, Kahramanmaraş Provincial Director of Environment and Forestry, for providing off-road vehicles for field work. P. Kiełtyk helped with the statistical analysis, which we gratefully acknowledge. We also wish to thank two anonymous referees for their useful comments on the manuscript and A.F.G. Dixon for linguistic correction.

\section{REFERENCES}

Ansaripour A., Aghasi K. \& Bedoreh M. 2012: Density and sex ratio of seven spotted ladybird (Coccinella septempunctata) in three altitudes of Khorramabad district. - Life Sci. J. 9: 830-834.

AtAeva M. 1972: On hibernation of some coccinellids on the southern slopes of Gissar Range and in Gissar Valley in Tajikistan. - Izv. A. N. Tadj. SSR, Otd. Biol. Nauk 2(47): 63-66 [in Russian].

BATTIN J. 2004: When good animals love bad habitats: ecological traps and the conservation of animal populations. - Conserv. Biol. 18: 1482-1491.

BoDENHEIMER F.S. 1943: Studies on the life-history and ecology of Coccinellidae: I. The life-history of Coccinella septempunctata L. in four different zoogeographical regions (Coleoptera: Coccinellidae). - Bull. Soc. Fouad 1er (Entomol.) 27: 1-28.

CERYNGIER P. 2000: Overwintering of Coccinella septempunctata (Coleoptera: Coccinellidae) at different altitudes in the Karkonosze Mts, SW Poland. - Eur. J. Entomol. 97: 323-328.

Ceryngier P., Roy H.E. \& Poland R.L. 2012: Natural enemies of ladybird beetles. In Hodek I., van Emden H.F. \& Honěk A. (eds): Ecology and Behaviour of the Ladybird Beetles (Coccinellidae). Blackwell, Chichester, pp. 375-443.

HodeK I. 1960: Hibernation-bionomics in Coccinellidae. - Čas. Čs. Spol. Entomol. 57: 1-20 [in Czech, English abstr.]. 
Hodek I. 2012: Diapause/dormancy. In Hodek I., van Emden H.F. \& Honĕk A. (eds): Ecology and Behaviour of the Ladybird Beetles (Coccinellidae). Blackwell, Chichester, pp. 275-342.

Hodek I. \& Michaud J.P. 2008: Why is Coccinella septempunctata so successful? (A point-of-view). — Eur. J. Entomol. 105: $1-12$.

Hodek I., IPerTi G. \& Hodková M. 1993: Long-distance flights in Coccinellidae (Coleoptera). — Eur. J. Entomol. 90: 403-414.

HoNĚK A. 1989: Overwintering and annual changes of abundance of Coccinella septempunctata in Czechoslovakia (Coleoptera, Coccinellidae). - Acta Entomol. Bohemoslov. 86: 179-192.

Katsoyannos P., Stathas G.J. \& Kontodimas D.C. 1997a: Phenology of Coccinella septempunctata (Col.: Coccinellidae) in central Greece. - Entomophaga 42: 435-444.

Katsoyannos P., Kontodimas D.C. \& Stathas G.J. 1997b: Summer diapause and winter quiescence of Coccinella septempunctata (Col. Coccinellidae) in central Greece. - Entomophaga 42: 483-491.

KRISTAN W.B., III. 2003: The role of habitat selection behavior in population dynamics: source-sink system and ecological traps. -Oikos 103: 457-468.

Lacey L.A. 1997: Manual of Techniques in Insect Pathology. Academic Press, San Diego, 409 pp.

Lipa J.J., Pruszyński S. \& BartKowski J. 1975: The parasites and survival of the lady bird beetles (Coccinellidae) during winter. - Acta Parasitol. Pol. 23: 453-461.

Mills N.J. 1981: The mortality and fat content of Adalia bipunctata during hibernation. - Entomol. Exp. Appl. 30: 265-268.

ÖzBeK H. \& Çetın G. 1991: Contribution to the fauna of Coccinellidae (Coleoptera) from eastern Anatolia along with some new records from Turkey. - Türk. Entomol. Derg. 15: 193-202.
Purcell K.L. \& Verner J. 1998: Density and reproductive success of California towhees. - Conserv. Biol. 12: 442-450.

Rehner S.A., Minnis A.M., Sung G.-H., Luangsa-ard J.J., Devotto L. \& Humber R.A. 2011: Phylogeny and systematics of the anamorphic, entomopathogenic genus Beauveria. - Mycologia 103: 1055-1073.

Ricci C., Ponti L. \& Pires A. 2005: Migratory flight and prediapause feeding of Coccinella septempunctata (Coleoptera) adults in agricultural and mountain ecosystems of Central Italy. - Eur. J. Entomol. 102: 531-538.

Ries L. \& Fagan W.F. 2003: Habitat edges as a potential ecological trap for an insect predator. - Ecol. Entomol. 28: 567-572.

RoBERTSON B.A. \& HutTo R. 2006: A framework for understanding ecological traps and an evaluation of existing evidence. Ecology 87: 1075-1085.

Sakurai H., Hirano T. \& Takeda S. 1986: Physiological distinction between aestivation and hibernation in the lady beetle, Coccinella septempunctata bruckii (Coleoptera: Coccinellidae). - Appl. Entomol. Zool. 21: 424-429.

SAVOISKAYA G.I. 1966: Hibernation and migration of coccinellids in south-eastern Kazakhstan. In Hodek I. (ed.): Ecology of Aphidophagous Insects. Academia, Prague, pp. 139-142.

Schlaepfer M.A., Runge M.C. \& Sherman P.W. 2002: Ecological and evolutionary traps. - Trends Ecol. Evol. 17: 474-480.

Zhou X., HoneK A., Powell W. \& Carter N. 1995: Variations in body length, weight, fat content and survival in Coccinella septempunctata at different hibernation sites. - Entomol. Exp. Appl. 75: 99-107.

Received May 28, 2014; revised and accepted July 30, 2014 Prepublished online October 15, 2014 